programme is recognized for identifying exceptional young conservationists, investing in their professional development, and providing a platform from which they become leaders.

When it was launched in 1985 as the Conservation Expedition Awards, the primary objective was to fund British university students to collect baseline data on threatened species. These grants have grown into what are now known as CLP Conservation Awards, with three stages of support. The focus has also shifted to support nationals living and working in lesser-developed countries, with the intention to build a cadre of local conservation leaders. Funding is initially awarded to advance small-scale conservation and research projects, and continuation funding helps teams establish longer-term initiatives with the potential to offer more sustainable solutions to conservation issues.

The Programme's investment is complemented by support for professional development, including short-term training courses and internship placements with the CLP partner organizations, as well as travel grants and networking and mentoring opportunities for CLP alumni. Projects have had significant impacts and been recognized for their contribution to biodiversity conservation by governments, the scientific community and conservation practitioners. Highlights of the Programme include the following examples:

- In 1988 a team was funded to survey the avifauna of Gola Forest, the largest area of intact lowland rain forest in Sierra Leone. The project led to a partnership agreement with the forest department, the Conservation Society of Sierra Leone and the Royal Society for the Protection of Birds. In 2011 the government of Sierra Leone declared this area the Gola Rainforest National Park.

- In 1996 activities initiated under Project Swallow Reef later resulted in the establishment of a permanent marine research and monitoring station on Layang Layang, supporting the conservation of one of the most biodiverse coral reefs in Malaysia.

- In 2009 a 3,000 ha nature reserve was established in Guangxi province, China, to conserve the world's rarest primate, the Critically Endangered cao-vit gibbon Nomascus nasutus, and its habitat, as a result of a CLP-funded project.

- Following initial sighting of a new primate species in Brazil, a team funded by CLP collected data that led to the description of a new species of Titi monkey Callicebus miltoni in 2015.

With the support of Oryx-The International Journal of Conservation, CLP also runs a week-long workshop to encourage alumni to publish their findings in peer-reviewed journals. In February 2015 CLP ran its 6th Writing for Conservation workshop, for 20 participants from Indonesia. Approximately 100 CLP alumni have now taken this training since 2008, resulting in publication of articles in a range of peer-reviewed journals.

The legacy of the Programme spans 4 decades. In April 2015 the Programme announced its latest Conservation Award winners, with a total of USD 300,000 granted to 22 projects in 12 countries. Results from CLP projects are published in project reports and are freely accessible via the CLP website. Further information can be found at http://www. conservationleadershipprogramme.org

Stuart Paterson Fauna \& Flora International, Cambridge, UK. E-mail stuart.paterson@fauna-flora.org

RoByn DALZEN BirdLife International, Cambridge, UK

\section{Community forest rights established for baobab conservation in Madagascar}

December 2014 marked a significant step towards effective conservation of the iconic, Endangered Grandidier's baobab Adansonia grandidieri, endemic to western Madagascar. Despite its high cultural significance in Madagascar, the species has limited protection from overexploitation. Non-timber forest products from the species, including bark, fibres, leaves, fruits and seeds, are utilized for various purposes, and particularly for food, medicine, construction and oil production, and to generate a small income. Local people recognize that the species is most heavily used 'when people don't have money' (Biodiversity Conservation, 2009, 18, 2759-2777), suggesting that the species may be at risk of overexploitation.

Supported by the Global Trees Campaign, the NGO Madagasikara Voakajy has been working closely with local communities to secure management rights to key baobab forests. This will allow communities to manage the forests sustainably to avoid deforestation and the overexploitation of the species. Towards the end of 2013 the team secured the transfer of forest management rights to the community in the village of Bepeha in the west. The site covers 6,453 ha of forest, with 400 adult Grandidier's baobabs.

Building on the successful transfer of rights in 2013, the process was replicated in December 2014 for a second village, Betainkilotra. As before, a new management plan was developed, outlining natural resource use within different forest zones: a core conservation zone (the critical area for baobabs), a subsistence use zone and a third area for reforestation. The communities will be supported and monitored in the implementation of the plan by the Direction Régionale de l'Environnement et des Forêts.

The Global Trees Campaign and Madagasikara Voakajy continue to support a similar process in Ambodimadiro in northern Madagascar. This site supports a population of c. 500 Endangered Diego's baobab Adansonia suarezensis. 
A management plan for the area was developed with communities in April 2015 and has been submitted to the local Direction Régionale de l'Environnement et des Forêts. It is hoped this work can successfully replicate progress in the west of the country.

Victoria PRICE Fauna \& Flora International, Cambridge, UK. E-mail victoria.price@fauna-flora.org

JULIE RAZAFIMANAHAKA and DAUDET ANDRIAFIDISON Madagasikara Voakajy, Antananarivo, Madagascar

\section{Slow loris arm key-rings}

In March 2015, after attending a workshop that was partly aimed at finding solutions to the ongoing illegal wildlife trade along China's southern borders, we had the opportunity to visit the Chinese border town of Daluo and its sister-town across the border in Myanmar, Mong La. Based on research conducted during 2006-2014 Nijman et al. (Primate Conservation, 2014, 28, 139-142) identified Mong La as a major trading centre for Bengal slow lorises Nycticebus bengalensis. The Bengal slow loris is categorized as Vulnerable on the IUCN Red List, partially because of rampant illegal trade, and is protected under both Myanmar and Chinese law. International trade in all eight species of slow loris is prohibited as the genus is listed in Appendix I of CITES, to which both Myanmar and China are signatories. In Mong La we observed two live Bengal slow lorises, two freshly killed, 15 skeletons, three skins, five slow loris arms and three bundles of 15 slow loris arms turned into key-rings, all openly for sale. Combined, these represent the remains of at least 32 Bengal slow lorises. We did not observe any Bengal slow lorises in Daluo-the market contained low numbers of wildlife, with the traders informing us of recent heightened presence of enforcement agency's staff, most likely in anticipation of the international workshop-but in July 2014 Axel Hofford, a journalist with the Guardian newspaper, photographed three (potentially up to five) slow loris key-ring chains in Daluo. Trade in Mong La is geared towards the Chinese market, with most wildlife observed in Daluo originating from the Mong La market across the border. The trade in slow lorises in Mong La and Daluo is in violation of Myanmar and Chinese domestic legislation and also of CITES regulations. The use of Bengal slow loris arms and other body parts in traditional Asian medicine is well known to us. We have seen a multitude of animal parts being used as key-rings, including the tails of many mammal species, and live newts, freshwater turtles and fish, each in their own little plastic container. We have not, however, previously seen slow loris arms in use as key-rings (we saw none during earlier visits to Mong La). Could our observations in Mong La and Daluo be the early signs of an emerging trend?

VINCENT NIJMAN and K.A.I NEKARIS Oxford Brookes University, Oxford, UK. E-mailvnijman@brookes.ac.uk

NABAJIT DAS Primate Research Centre NE India, Guwahati, India

MINGXIA Zhang Center for Integrative Conservation, Xishuangbanna Tropical Botanical Garden, Chinese Academy of Sciences, Yunnan, China

\section{Conserving the world's rarest ape: action planning for the Hainan gibbon}

The Critically Endangered Hainan gibbon Nomascus hainanus is the rarest ape and possibly rarest mammal species, comprising a single population of c. 25 individuals in Bawangling National Nature Reserve, Hainan, China. The species occurred historically across Hainan, with an estimated population of c. 2,000 in the 1950s, but experienced a precipitous decline during the 2oth century driven by hunting and extensive habitat loss. Periodic surveys since 2003 have failed to locate any individuals outside the Reserve, and there are no captive populations.

Research over the past 3 decades has clarified key aspects of Hainan gibbon biology, behaviour and ecology, and conservation legislation is in place to protect the last population: Bawangling was gazetted as a protected area in 1980 and the species was designated a State 1 Protected Species under the 1988 Chinese Wildlife Protection Law. The first Conservation Action Plan for the species was produced in 2005 , focusing primarily on threat abatement. Subsequent management activities have included efforts to protect and restore gibbon habitat, and there has been some apparent growth in the gibbon population. However, the tiny size of the sole population threatens the long-term survival of the species.

To promote effective conservation of the Hainan gibbon a conservation planning workshop was held during 18-20 March 2014 in Bo'ao, Hainan. This international workshop was organized by the Zoological Society of London in cooperation with the Hainan Bawangling National Nature Reserve Management Office and the IUCN Species Survival Commission China Primate Specialist Group, with support from Kadoorie Farm \& Botanic Garden and Fauna \& Flora International, and was facilitated by the IUCN Species Survival Commission Conservation Breeding Specialist Group. Financial support was provided by the Arcus Foundation and the Mohamed bin Zayed Species Conservation Fund. Over 100 stakeholders participated, including experts in gibbon conservation and small population recovery programmes, and representatives 